\title{
Pemuda, Politik dan Masa Depan Indonesia $2045^{12}$
}

\author{
Achmad Zulfikar ${ }^{3}$
}

\section{Pendahuluan}

Pemuda dalam lintasan sejarah senantiasa mengambil peran strategis dalam menentukan nasib suatu bangsa. Hal ini telah dibuktikan bangsa Indonesia dalam proses menuju Kemerdekaan, saat memproklamirkan Kemerdekaan hingga hari ini dan masa yang akan datang. Dimulai dengan peristiwa Sumpah Pemuda tahun 1928 yang tercetus pada Kongres Pemuda II tanggal 28 Oktober 1928. Di momen bersejarah itu, pemuda Indonesia yang berasal dari berbagai penjuru negeri Hindia Belanda mengikrarkan bertanah air satu, berbangsa satu dan berbahasa satu: Indonesia (Tirto.id, 2019).

Berbagai peristiwa setelah Sumpah Pemuda semakin menguatkan basis-basis perlawanan terhadap kekuatan bangsa kolonial. Hingga, perjuangan tersebut bermuara pada Proklamasi Kemerdekaan Republik Indonesia pada 17 Agustus 1945 yang juga melibatkan peran pemuda dalam upaya meyakinkan kedua Proklamator, bung Karno dan bung Hatta untuk segera memproklamasikan kemerdekaan Indonesia. Hingga hari ini, para pemuda yang mengisi Kemerdekaan telah melakukan kontribusi di berbagai sektor, hingga menghasilkan berbagai karya dan inovasi.

Namun demikian, kekhawatiran justru datang dari proyeksi masa depan Indonesia. Di tahun 2045 yang bertepatan dengan 100 Tahun Kemerdekaan Indonesia yang juga menjadi masa Bonus Demografi dengan jumlah penduduk usia produktif dengan proporsi yang besar. Pemuda Indonesia kembali ditantang untuk mengambil peran strategis. Jika pemuda mampu membangun kapasitas menuju Indonesia Emas 2045, maka saat bonus demografi tersebut, potensi usia produktif dapat dioptimalkan. Tetapi, jika pemuda gagal membangun kapasitas, maka bonus demografi justru akan menjadi beban bagi bangsa dan negara.

Sehingga, dibutuhkan upaya untuk membangun kapasitas pemuda sejak dini. Salah satunya dengan mendekatkan pemuda dengan politik. Pemuda menurut Kamus Besar Bahasa Indonesia (KBBI), orang muda (laki-laki); remaja; taruna. Sedangkan, Politik menurut Kamus Besar Bahasa Indonesia dapat dimaknai sebagai segala urusan dan tindakan

\footnotetext{
1 Opini/Esai yang diikutsertakan dalam Lomba Menulis Kepemudaan \& Sejarah Usia Muda Pahlawan Indonesia dalam rangka memperingati Bulan Pemuda dan Hari Pahlawan Tahun 2019 diselenggarakan oleh Deputi Bidang Pengembangan Pemuda, Kementerian Pemuda dan Olahraga Republik Indonesia 2 Opini telah dipublikasikan daring melalui: http:/ / www.pijarnews.com/ opini-pemuda-politik-dan-masadepan-indonesia-2045/ pada tanggal 12 November 2019.

${ }^{3}$ Achmad Zulfikar, S.IP., M.Si., M.H. yang akrab disapa Azkar merupakan Inisiator Gerakan Pemuda Makassar Kawal Pemilu dan Demokrasi. Pada Pemilu Serentak 2019 lalu, ia terlibat aktif sebagai Relawan Demokrasi KPU Kota Makassar. Azkar merupakan akademisi yang telah dipercaya untuk mengajar pada Program Studi Ilmu Politik Universitas Hasanuddin, Program Studi Ilmu Hubungan Internasional Universitas Muhammadiyah Yogyakarta dan Program Studi Ilmu Hubungan Internasional Universitas Fajar. Azkar juga saat ini menjabat sebagai Sekretaris Jenderal pada Perkumpulan Sarjana Hubungan Internasional Indonesia (PaSHII), serta aktif pada Mata Garuda Sulawesi Selatan: Alumni Penerima Beasiswa LPDP. Azkar juga mengembangkan Makassar Development Institute (MDI) dan Institute of Political and Social Studies (IPOLSS). Azkar dapat dihubungi melalui surat elektronik (surel): apa@kabarfikar.com.
} 
(kebijakan, siasat dan sebagainya) mengenai pemerintahan negara. Jika kedua kata ini disandingkan maka pemuda dalam politik merujuk pada keterlibatan orang muda/remaja dalam proses pengambilan keputusan (kebijakan) mengenai pemerintahan, termasuk dalamnya proses politik (Pemilu) dan partisipasi masyarakat.

Opini/esai ini bertujuan untuk mengungkap prospek Pemuda dalam politik menuju Indonesia Emas 2045. Sebagaimana telah dipaparkan bahwa sejarah menunjukkan pemuda memegang peran strategis bangsa, termasuk bangsa Indonesia. Sehingga, pemuda dengan berbagai potensinya dapat kembali membuktikan perannya dalam menyukseskan periode bonus demografi pada tahun 2045 .

\section{Pembahasan}

\section{Pemuda: Dulu, Kini dan Nanti}

Secara historis, pemuda sebagai konstruksi sosial tidak terlepas dari konteks sosiokultural yang melingkupinya. Dalam tradisi Anglo-Saxon misalnya, Wyn (2016) menjelaskan bahwa pemuda muncul sebagai kategori yang baru dalam masyarakat sebagai respon terhadap perubahan sosial yang dimotori oleh kapitalisme, industrialisasi, dan urbanisasi. Pemuda muncul sebagai sebuah kategori baru guna merespon kebutuhan akan tenaga kerja supaya roda akumulasi profit dan industrialisasi berjalan dengan mulus.

Pemuda memiliki dua sisi wajah yang saling berhimpitan yaitu budaya kaum muda (youth culture) dan transisi pemuda (youth transition) ini menjadi realitas kompleks yang harus dinegosiasikan oleh pemuda dalam kehidupan sehari-hari. Dalam kedua domain inilah pemuda dikonstruksikan oleh institusi-institusi eksternal di luar dirinya sekaligus secara aktif, sebagai agensi, melakukan resistensi terhadap pihak-pihak yang mencoba mengontrol dan melakukan klaim secara sewenang-wenang mengenai betapa 'toxic'-nya pemuda. Dalam kajian kepemudaan, kedua domain ini acapkali dikonstruksikan sebagai entitas yang terpisah. Namun dalam kenyataan empiris, kedua domain ini tidak bisa dipisahkan satu sama lain. (Sutopo, 2016)

Selanjutnya dalam perkembangannya setiap generasi pemuda memiliki pola yang berbeda. Dalam hal ini, kontekstual zaman sangat berperan aktif dalam menentukan disposisi dari sebuah generasi. Berkenaan dengan hal tersebut, agaknya dalam menyikapi keberagaman ini dirasa tepat menggunakan pendekatan dari telaah teknologi media. Secara lebih lanjut, kajian media mengklasifikasikan pemuda menjadi: Generasi Baby-boomer, generasi X, dan generasi Y. (Raditya, 2015)

Sedangkan, dugaan Buckingham lebih spesifik dengan klasifikasi pemuda berdasarkan pasar komersial. Dugaan pasar komersial tersebut menunjukan adanya pola tertentu yang merujuk pada penggunaan tekonologi. Buckingham (2008:4) menyatakan bahwa: The invention and use of a category like "Generation X" (and its subsequent mutations) reflects both the importance and the complexity of age-based distinctions in contemporary consumer culture. Pembedaan tersebut berkelindan akan generasi, konsumsi, dan kemajuan zaman.

Perbedaan generasi dan konsumsi ini turut membentuk pola pikir, serta kebiasaan dari para pemuda. Secara spesifik, Sarwono pun turut mengungkapkan bahwa: satu ciri khas dari generasi baby-boomer yakni gagap teknologi. Jangan memainkan gadget, memindahkan 
saluran TV dengan alat kontrol jarak jauh pun masih lebih suka minta bantuan cucu. Karena itu, generasi baby-boomer lebih mengandalkan jaringan dunia nyata yang dasarnya sejak dulu adalah perkoncoan, kekeluargaan, dan primordialisme yang dipertahankan melalui tradisi dan penokohan orang-orang tertentu berdasarkan keturunan yang cenderung feodalistik.

Selanjutnya, watak generasi X dan Y tidak sabaran, bukan hanya mendambakan perubahan, tetapi betul-betul ditabrak oleh perubahan yang sangat cepat sehingga kalau tidak ikut berubah maka akan digilas oleh perubahan itu sendiri. Generasi X dan Y sangat lentur, cepat menyesuaikan diri, anti kemapanan, siapa yang mau maju cepat akan berlari kencang tidak peduli pada senioritas, kurang peduli pada sistem, prosedur, dan birokrasi, bergantiganti pekerjaan tidak masalah selama pendapatannya meningkat terus. Sehingga, tidak dibutuhkan lagi satu sumber informasi, karena bisa mengakses informasi dari 1001 sumber hanya dengan memencet tombol-tombol telepon seluler, dengan jari jempol. Jaringan desa terbangun melalui dunia maya, yang lebih impersonal dan jauh dari primordialisme dan feodalisme. (Sarwono, 2016)

Dari penjelasan di atas, telah jelas perbedaan sikap dan logika akan pemuda yang didasarkan pada generasi. Pembahasan ini tidak dilakukan untuk mencari keunggulan dari salah satu generasi, namun melihat sejauh mana perkembangan dan logika berfikir pemuda di tiap zaman. Dengan adanya generasi milenial, sebuah kemajuan yang bernama teknologi telah menghasilkan kekuatan intelektual baru, bahkan struktur otak yang lebih kompleks, sebuah cara baru membentuk identitas, dan kepribadian yang lebih beragam. (Raditya, 2015)

\section{Partisipasi Politik}

Partisipasi politik merupakan aspek penting dalam sebuah tatanan negara demokrasi sekaligus merupakan ciri khas adanya modernisasi politik. Di negara-negara yang proses modernisasinya secara umum telah berjalan dengan baik, biasanya tingkat partisipasi politik warga negara meningkat. Modernisasi politik dapat berkaitan dengan aspek politik dan pemerintah.

Herbert McClosky mengemukakan pendapatnya tentang partisipasi politik sebagai: kegiatan-kegiatan sukarela dari warga masyarakat melalui mana peserta mengambil bagian dalam proses pemilihan penguasa, dan secara langsung atau tidak langsung, dalam proses pembentukan kebijakan umum). (Herbert McClosky dalam Miriam Budiarjo, 2015:367; Zulfikar, 2018)

Pada perspektif pengertian yang generik Miriam Budiarjo menyatakan bahwa partisipasi politik secara umum dapat didefinisikan sebagai kegiatan seseorang atau kelompok orang untuk ikut serta secara aktif dalam kehidupan politik, antara lain dengan jalan memilih pemimpin negara dan, secara langsung atau tidak langsung, memengaruhi kebijakan pemerintah (public policy).

Kegiatan ini mencakup tindakan seperti memberikan suara dalam pemilihan umum, menghadiri rapat umum, mengadakan hubungan (contacting) atau lobbying dengan pejabat pemerintah atau anggota parlemen, menjadi anggota partai atau salah satu gerakan sosial dengan direct action-nya, dan sebagainya. (Miriam Budiarjo, 2015:367)

Selanjutnya Ramlan Surbakti (2010:180) juga memberikan pengertian yang sejalan dengan pengertian partisipasi politik diatas yakni: partisipasi politik sebagai kegiatan warga 
negara biasa dalam mempengaruhi proses pembuatan dan pelaksanaan kebijakan umum dan ikut serta menentukan pimpinan pemerintahan. Partisipasi politik tersebut didefinisikan sebagai keikutsertaan warga negara dalam pembuatan dan pelaksanaan kebijakan publik yang dilakukan oleh warga negara biasa.

Berdasarkan beberapa pendapat yang dikemukankan oleh para ahli di atas dapat ditarik kesimpulan bahwa partisipasi politik adalah hal-hal yang berkaitan dengan kegiatan seseorang atau sekelompok orang secara sukarela dalam hal penentuan atau pengambilan kebijakan pemerintah baik itu dalam hal pemilihan pemimpin ataupun penentuan sikap terhadap kebijakan publik yang dibuat oleh pemerintah untuk di jalankan, yang dilakukan secara langsung atau tidak langsung dengan cara konvensional ataupun dengan cara non konvensional atau bahkan dengan kekerasan (violence).

\section{Prospek Pemuda dalam Politik Menuju Indonesia Emas 2045}

Pemuda di tiap generasi seperti yang telah dikemukakan sebelumnya memiliki karkteristik yang berbeda-beda. Sehingga, dibutuhkan pendekatan yang unik bagi setiap generasi pemuda. Memasuki era revolusi industri 4.0 dan society 5.0 (yang akan dimulai pada tahun 2020), perkembangan arus perubahan sosial berlangsung semakin cepat dan masif. Sehingga, muncullah berbagai macam fenomena pemuda kontemporer; dalam kajian transisi pemuda konvensional misalnya, terkait dengan tuntutan bagi pemuda untuk menjadi dewasa secara sukses (succesful transition to adulthood).

Pemuda dituntut untuk mempunyai pekerjaan, menikah dan menempati rumahnya sendiri dalam jangka waktu tertentu. Jika hal ini tidak terpenuhi maka transisi pemuda dianggap extended dan sangat mungkin didefinisikan sebagai gagal. Di sisi yang lain, perubahan sosial menuju era modernitas lanjut dan juga era hegemoni neoliberalisme membuat proses negosiasi dalam transisi pemuda menjadi semakin kompleks, rapuh dan rentan terhadap resiko-resiko yang tidak dapat diprediksi baik di masa sekarang maupun di masa depan. Yang semakin sering terjadi (Sutopo. 2016)

Sebagaimana telah dipaparkan pada bagian awal esai ini bahwa akan diungkap prospek pemuda dalam politik menuju Indonesia Emas 2045. Sebagaimana telah diketahui bahwa pada tahun 2045, Indonesia akan genap berusia 100 tahun. Pada masa itu, Indonesia diprediksi akan mengalami bonus demografi yaitu suatu kondisi dimana $70 \%$ warga negara negara berada pada usia produktif (15 - 64 tahun).

Kondisi ini dapat menjadi modal utama untuk menuju Indonesia emas 2045, yaitu Indonesia dengan ekonomi yang unggul dalam revolusi industri 4.0, Indonesia dengan pembangunan dan pendidikan berbasis riset yang mampu menghasilkan manusia dengan kemampuan berfikir kritis, kreatif serta berdaya saing global. Dua komponen penting dari visi ini yang dikategorikan ke dalam 2 poin utama yakni pembangunan Sumber Daya Manusia (SDM) serta pembangunan ekonomi yang berkelanjutan.

Pengembangan Sumber Daya Manusia (SDM) adalah bagian dari proses pembangunan nasional Indonesia dalam rangka menuju Indonesia Emas 2045. Terkait tujuan tersebut, maka kontribusi nyata generasi muda saat ini memainkan peran yang paling penting agar kecerdasan bangsa Indonesia dapat mengungguli bangsa-bangsa lain di dunia. Adapun 
aspek-aspek pengembangan sumber daya manusia tersebut terdiri dari aspek pendidikan dan juga kesehatan. (Kompasiana, 2019)

Selain itu, kontribusi generasi muda dalam pembangunan ekonomi berkelanjutan secara realistis dapat dilihat dengan munculnya entrepreneur, serta startup founder yang menghasilkan berbagai lapangan pekerjaan baru, sehingga mampu membantu pemerintah dalam menyerap tenaga kerja, mengurangi tingkat pengangguran dan pada akhirnya meningkatkan pertumbuhan ekonomi secara nasional.

Beberapa prospek bagi pemuda dalam politik menuju Indonesia Emas 2045 antara lain: memaksimalkan pengembangan SDM, diperlukan materi pendidikan yang lebih implementatif dan sesuai dengan perkembangan teknologi seperti entrepreneurship, critical thinking, problem solving dan kreativitas.

Sehingga generasi muda kedepannya mampu bersaing dengan tantangan global yang akan datang, mempersiapkan generasi muda dengan dasar bisnis dan kewirausahaan yang selaras dengan perkembangan teknologi sehingga generasi muda nantinya tidak hanya membutuhkan lapangan kerja tapi juga mampu membuat lapangan pekerjaan yang lebih adaptif dan berdampak dengan memanfaatkan teknologi.

\section{Kesimpulan}

Berdasarkan penjelasan di atas, maka dapat disimpulkan bahwa pemuda dalam politik menuju Indonesia Emas 2045 memiliki prospek yang baik. Dimulai dengan peran strategis pemuda dalam berbagai peristiwa penting bangsa Indonesia, di samping itu juga pemuda dituntut memiliki berbagai keterampilan agar mampu mengoptimalkan potensi terbaiknya.

\section{References}

Desiana Rizka Fimmastuti, Agus Pramusinto dan Djoko Soerjo. Persepsi dan Tindakan Politik Pemuda terhadap Gerakan Jogja Independent (JOINT) dalam Pelaksanaan Pilwalkot Kota Yogyakarta Tahun 2017 dan Implikasinya terhadap Ketahanan Politik Pemuda: Studi Pada Relawan Jogja Independent (JOINT) di Kota Yogyakarta. Jurnal Ketahanan Nasional Vol. 24 No. 1 (2018), pp. 117-134.

KBBI. Pemuda. Diakses dari: https://kbbi.web.id/pemuda, pada tanggal 1 November 2019.

KBBI. Politik. Diakses dari: https://kbbi.web.id/politik , pada tanggal 1 November 2019.

Kompasiana. Kontribusi Generasi Muda Indonesia Emas 2045. Diakses dari: https://www.kompasiana.com/buatsg/5cd9f7f23ba7f767ee36cdcc/kontribusi-generasi-mudamenuju-indonesia-emas-2045 pada 1 November 2019.

Raditya, Michael H. B. Mencermati Logika Politik Pemuda dari Pola Menikmati Musik. Jurnal Studi Pemuda Vol. 4 No. 1, Mei 2015, pp. 152-161.

Sutopo, Oki Rahadianto. Pemuda dan Resistensi: Sebuah Refleksi Kritis. Esai. Jurnal Studi Pemuda Vol. 5, No. 2, September 2016, pp. 502-506

Tirto.id. (2019). Isi, Makna \& Sejarah Hari Sumpah Pemuda 28 Oktober 1928. Diakses dari: https://tirto.id/isi-makna-sejarah-hari-sumpah-pemuda-28-oktober-1928-eku2, pada tanggal 1 November 2019.

Zulfikar, Achmad. (2018). Partisipasi Pemuda di Tahun Politik. Diakses dari: https://doi.org/10.31227/osf.io/7dbtr 